\title{
Lessons from the Training and Support of Teachers in the Development of Digital Skills: A case study of @prende 2.0
}

\author{
Ana Lidia Franzoni Velázquez \\ analidia@itam.com \\ Instituto Tecnológico Autónomo de México, México \\ María Cristina Cardenas Peralta \\ ccardenas.peralta@gmail.com \\ Instituto Tecnológico Autónomo de México, México

\section{José Ángel Mandujano Canto} \\ jmandujano@gmail.com \\ Instituto Tecnológico Autónomo de México, México
}

\begin{abstract}
Since 1997, Mexico - like many Latin American countries - has seen significant public and private investment aimed at incorporating information technology in the classroom. Inclass information technology holds the great promise of revolutionizing the teachinglearning process. The reality is different, often showing negligible impact from such efforts. One common criticism has been the failure to properly train and support teachers before rolling out technology for use in their classrooms. This article looks at a recent effort of the Mexican government to address the issue of teacher training and support. @prende 2.0 was a program of the Mexican federal government that involved 2,700 digital trainers who trained more than 63,000 teachers in the use of technological equipment that they would be provided. Analyzing administration information and hard data from @prende, this article analyzes the program's successes and challenges to fashion a series of recommendations regarding similar training and support efforts.
\end{abstract}

\section{Keywords}

Teacher training; Digital Skills; evidence of learning 


\section{Introduction}

Studies published by international institutions show that the effectiveness of information technology in the learning environment hinges, in large part, on the digital skills of the teachers utilizing that technology and the support provided to them. It is unsurprising, therefore, that there has been sustained interest in evaluating efforts to develop and strengthen teachers' digital skills and establishing a methodology for assessment. Evaluators have faced difficulties, however, given the paucity of innovative systems to form better educators and the difficulty in preserving training efforts over time (Murillo, 2005, p. 11-12).

In Latin America, countries have attempted various training programs for teachers. Despite considerable expense, the results achieved so far have been distant from desirable. Exploring the lack of results, Cardelli and Duhalde (2001) have observed that regional educational assumptions emphasize teaching as the transmission of information; and learning as passive assimilation of that information, which is in considerable tension with the use of information for the production of content.

Mexico has a history of incorporating Information and Communication Technologies (ICT) into the teaching and learning process. These efforts centered on the technology being implemented, relegating teacher training to a lesser position. The @prende 2.0 program represented a break from this pattern, in that it was not focused on the technological equipment per se. Rather, it sought to promote teacher training as the key element for the successful incorporation of ICTs. To do so it promoted collaboration with the Mexican states, which had the best insights into the educational realities and needs.

\section{a. Background - Previous Programs}

The incorporation of ICTs in the Mexican education system started in 1997, with the School Network Program (Programa Red Escolar, 1997-2004). This program allowed students, teachers, principals and parents to communicate through networks on the internet. Its approach was based on projects of technology use and was overseen by a Technical Pedagogical Advisor (Asesor Técnico Pedagógico).

After that initiative, Enciclomedia (2003-2011) was established. This program consisted in equipping classrooms with a computer, a projector, an electronic white-board, a computer table and a printer. This was intended to help in teaching of the current curriculum and the teacher was responsible for the use of the technological equipment.

The program that followed, Digital Skills for All (Habilidades Digitales para Todos, 2009-2012), sought to promote digital skills in students and teaching staff in telematic classrooms. This initiative also promoted training performance indicators and certification.

With a change of government, a new initiative was put into place, "Mi Compu.mx" (2013-2014). This program delivered just over 240,000 portable computers with Linux operating systems to students in $5^{\text {th }}$ and $6^{\text {th }}$ grade primary schools in three different states. The program sought to inspire the use of technology as a tool and object of learning.

During the 2014-2015 school year, the program - which changed its name to the Inclusion and Digital Literacy Program (Programa de Inclusión y Alfabetización Digital), gave out 708,824 tablets and technological equipment accesories, in six states. They were given to $5^{\text {th }}$ grade primary school children in just over 16,000 public schools. The equipment contained pre-loaded material for $5^{\text {th }}$ grade students, computer programs, and content for the family. The server for the classroom sets had digital educational resources pre-loaded for $6^{\text {th }}$ grade students. During this period, 8,096 educators were trained. 
For the next school year, the program changed its name to Program of Digital Inclusion (Programa de Inclusión Digital). It reached 15 states, giving 1,073,174 tablets with the Windows operating system to $5^{\text {th }}$ grade primary-school students and 71,480 tablets to teachers in 32,000 schools.

A number of problems were common to these programs. First, the scope, no federal initiative prior to @prende.mx considered training and support of educational authorities (or teachers), particularly in light of the diversity and autonomy of the states of Mexico. Second, the teachers who had received equipment from preceding programs had not been properly trained. Instead, the distribution of devices - by and of itself - was considered the priority. Third, the programs did not record information about the use of equipment, and nor was there an assessment after the delivery of economic resources. Fourth, the programs did not have a specific strategy about inclusion in the transformation of the process of teaching and learning.

Most fundamentally, every change of government produced different expectations and focus. There was no real continuity, thus experience and resources were lost. It is this last point about the loss of experience and resources that provides the impetus for this article, which seeks to fairly assess the work of @prende.mx in order to understand best practices related to teacher training, with the intention of making a lasting contribution to future projects in Mexico and abroad.

\section{Methodology}

Beginning in the 2016-2017 school year, the General Coordination of @prende.mx (GC@) - an independent body that operated @prende.mx within the Secretary of Public Education (SEP) designed and implemented a training and support program that aimed to achieve the incorporation of information technology as a learning tool. This took place in the 15 states which had already received tablets during the 2015-2016 school year - under the previous program (the aforementioned Programa de Inclusión Digital).

The program's objective was to develop digital skills and thinking through training and support. More practically, the program planned to offer digital educational resources through a digital platform. To do so, it forged strategic alliances with international organizations, academics, local government, non-governmental organizations, and business.

Taking into account all of the previous experience, the following methodology was designed. It aimed to minimize the problems previously encountered. The methodology had 6 stages:

- Stage 0: Establishment of training objectives

- Stage 1: Definition of training strategy

- Stage 2: Analysis of relevance of the training

- Stage 3: Identification of associated costs

- Stage 4: Qualitative analysis of the strategies

- Stage 5: Analysis of the evidence

\section{a. Developing the Methodology}

\section{Stage 0: Establishment of training objectives}

The selection of training objectives was based on a review of existing frames of reference. These were the NETS-S framework from ISTE, the DIGCOMPEDU from the European Commission, and the Competency Framework for Teachers from UNESCO (UNESCO, 2016). Having compared them, the UNESCO framework was chosen because it proposes international standards by which to assess teacher skills in their use and incorporation of ICT. It defines levels and indicators by which to assess teacher performance. These are shown below: 


\begin{tabular}{|c|c|c|}
\hline $\begin{array}{l}\text { Level 1: } \\
\text { Basic } \\
\text { knowledge of } \\
\text { ICT }\end{array}$ & $\begin{array}{l}\text { Use of information } \\
\text { technology as a tool } \\
\text { for production, } \\
\text { management and } \\
\text { practice. }\end{array}$ & $\begin{array}{l}\text { The teacher demonstrates a basic level of information } \\
\text { technology management, using digital resources to guide } \\
\text { the student in their learning. } \\
\text { Use of productive tools, multimedia, searches for } \\
\text { information on the internet, and communication using } \\
\text { social networks. }\end{array}$ \\
\hline $\begin{array}{l}\text { Level 2: } \\
\text { Deeper } \\
\text { knowledge of } \\
\text { ICT }\end{array}$ & $\begin{array}{l}\text { Solving problems via } \\
\text { the use of } \\
\text { information } \\
\text { technology. }\end{array}$ & $\begin{array}{l}\text { The teacher acts as a manager and guide for projects } \\
\text { that consider real problems. } \\
\text { Use of more sophisticated technologies, such as } \\
\text { simulators, thematic search engines, and / or } \\
\text { collaboration tools }\end{array}$ \\
\hline $\begin{array}{l}\text { Level 3: } \\
\text { Generation o } \\
\text { knowledge. }\end{array}$ & $\begin{array}{l}\text { Creation of } \\
\text { innovative products } \\
\text { via information } \\
\text { technology }\end{array}$ & $\begin{array}{l}\text { The teacher supports their students in the creation of } \\
\text { products with information technology and promotes the } \\
\text { planning and management of their objectives and } \\
\text { activities. Demonstrates a wide understanding of } \\
\text { information technology and uses programming and } \\
\text { robotics to promote computational thinking. }\end{array}$ \\
\hline
\end{tabular}

Table 1: UNESCO teacher's framework

Source: https://unesdoc.unesco.org/ark:/48223/pf0000371024

GC@ asked states to focus only on level 1 to establish a baseline of the strengths and weaknesses of teachers at this level. Also, although the GC@ defined nine digital skills important to students, it focused on four of these for the level requested of teachers:

\begin{tabular}{|c|l|}
\hline Skill & \multicolumn{1}{c|}{ Definition } \\
\hline $\begin{array}{c}\text { Use of information } \\
\text { technology }\end{array}$ & $\begin{array}{l}\text { The ability to use basic functions of devices and operating systems; to } \\
\text { know and apply basic rules of care and safety in the use of devices; to } \\
\text { master a wider range of applications like educational software and } \\
\text { productivity tools; to use basic functions of communication tools over the } \\
\text { internet. }\end{array}$ \\
\hline Digital citizenship & $\begin{array}{l}\text { The ability to respect personal details and intellectual property; to protect } \\
\text { information in digital environments; to distinguish between opportunities } \\
\text { and personal risks in order to apply personal security strategies for self and } \\
\text { others; to understand the impact - both positive and negative - that ICT } \\
\text { has on people and society. }\end{array}$ \\
\hline Self-monitoring & $\begin{array}{l}\text { The ability to define objectives; to self-assess performance through } \\
\text { feedback; to develop responsibility and initiative in learning; to promote } \\
\text { creativity and to organize and manage time. }\end{array}$ \\
\hline thinking & $\begin{array}{l}\text { The ability to form problems in such a way that computers, tablets or other } \\
\text { tools can be used for their solution; to organize data in logical ways in } \\
\text { order to analyse it; to represent data abstractly - as models and }\end{array}$ \\
\hline
\end{tabular}




\begin{tabular}{|l|l|}
\hline & $\begin{array}{l}\text { simulations; to automate solutions using algorithms; to identify, analyse } \\
\text { and implement solutions with a view to efficiency; to generalize and } \\
\text { transfer the problem solving process. }\end{array}$ \\
\hline
\end{tabular}

Table 2: Digital Skills

Source: General Coordination @prende.mx

\section{Stage 1: Definition of training strategy}

The proposed strategy was based on respecting state autonomy without compromising the quality of training. It aimed to do this by recognizing cultural diversity and differences between states in their current level of incorporation of technology (i.e. the metropolitan region has a high level of technological development, whereas in the Southern zone does not).

To fulfil the training strategy the GC@ asked states to:

A. Reach at least level 1 of the UNESCO ICT Competency Framework for Teachers.

B. Develop at least four digital skills that the GC@ promotes in its Digital Inclusion Program.

C. Complete the form sent with instructions from the GC@ about developing a training strategy. In these instructions, the GC@ requested that the states comply with the following:

a. Responsibility for the Digital Inclusion Program. The states were directed to name 4 people responsible for the program (including their full name, phone number and email address). Each had a different area of responsibility, so that effective communication could be established with those principally involved.

b. State measurements for training of educators involved in $6^{\text {th }}$ year of primary school.

c. Type of training. The states were required to describe the programs that would form their training strategy based on the UNESCO Frame of Reference (level one) using the following:

i. Type of resources that would be used in the training according to the needs of each state.

ii. Number of courses and their modality (face-to-face / online) with a general description of each (name of the training program; duration - number of hours; learning objectives; content to develop; web address of the program; type of institution that would deliver it; modality of the course; number of teachers to train; the date it would take place; the general budgets and the aspects of the UNESCO Frame of Reference that would be addressed).

iii. Type of monitoring and Assessment. The states would indicate the type of monitoring and assessment that the teachers would undertake after the training process.

\section{Stage 2: Analysis of relevance of the training.}

As the training strategies were received, GC@ proceeded to analyze them, taking into account the following requirements:

A. The training and support proposed was required to address Level 1 of the UNESCO Frame of Reference in the use of ICT in light of the 86 performance indicators proposed by the CG@ and shared with the states. The strategy had to cover at least $80 \%$ of these indicators. 
B. Training and support had to be directed at teachers and educationalists concerned with $6^{\text {th }}$ grade primary schools, since students from that grade had been given devices in the school year 2015-16.

C. Training need to be provided during the 2016-2017 school year.

\section{Stage 3: Identification of associated costs}

Each strategy was reviewed to ensure that the budget was distributed in such a way that it complied with the following: $70 \%$ of the cost of the training would go to the payment of trainers; ${ }^{1}$ $20 \%$ of the cost be for travel expenses ${ }^{2}$ and $10 \%$ of the cost for administrative purposes. ${ }^{3}$ To stop budget being invested in the development of educational platforms rather than teacher training, the administrative overhead portion was not an authorized part of the allocation of budget.

\section{Stage 4: Qualitative analysis of the strategies}

Once the costs were assessed, a qualitative analysis of each of the proposed strategies was undertaken, in order to adjust the assigned amounts. The following were considered:

- The proposed strategy went beyond courses related to the functioning of electronic tablets;

- It considered follow up and support;

- $\quad$ Face-to-face training was to last between 4 and 15 hours, within the school year. ${ }^{4}$

\section{Stage 5: Analysis of the evidence}

GC@ further analyzed the impact of ICT in the learning projects, complying with the relevant level of training and with the intention of forming digital skills in students. Its aim was to identify best practices so that these could be shared with other teachers from outside of the state.

\section{Results}

The results, shown below, are based on the methodological stages. To meet the requirements of stages 0 and 1 , each strategy was individually assessed to verify the timetable, content and feasibility of the delivery of training. Of the 15 states that received equipment under the Program of Digital Inclusion, two (the State of Mexico and Mexico City) did not receive resources because they trained their teachers relying on other funds.

In the analysis of the timetable, content, and feasibility of the delivery of the training, 11 of the 13 states submitted the form and training strategy correctly. Two states (Puebla and Sonora) filed the agreement and/or contract incorrectly.

\footnotetext{
${ }^{1}$ In the case where trainers were used to impart courses, this part of the budget allocation could be less than $70 \%$ (and as low as 0\%).

${ }^{2}$ This could be less than $20 \%$ and $0 \%$ in cases where the course was online.

3 This included the maintenance payments for the educational platform that the state already had. This could less than $10 \%$ (as low as $0 \%$ )

${ }^{4}$ This range was deemed optimal by the Programa Piloto de Alfabetización e Inclusión Digital (Pilot Program for Digital Literacy and Inclusion) developed by the Cordination of the Estrategia Digital Nacional (CEDN) de la Presidencia de la República (National Digital Strategy).
} 


\section{Stage 1: Definition of training strategy}

After reviewing each different strategy proposed by the 11 states that correctly submitted, a selection of themes was made. The most relevant content was classified according to the objectives and guidelines provided for the states by the CG@.

According to the proposals received, all of the states said that their training would address the use, application, content and solution of problems regarding the tablets, as well as teaching strategies for the use and incorporation of ICT in the classroom. Regarding the operating system, 9 states said that their training would include use of Microsoft, while only 3 also covered Google. The creation and shaping of didactic sequences were also mentioned by 9 states. Slightly over $70 \%$ proposed training in the use of the internet for educational purposes and for skills in digital citizenship. Five of 11 states proposed instruction about multimedia tools, another 4 addressed collaboration tools such as project based learning and social networks. It is striking that less than $30 \%$ of the proposals involved the use of the @prende platform, and only one state addressed computational thinking.

\section{Stage 2: Analysis of relevance of the training}

In order to assess the viability of each proposal, the following were considered: amount of hours for each course, the number of courses in each year, and the modality of implementation.

\begin{tabular}{|l|c|c|c|c|l|c|c|}
\hline \multirow{2}{*}{ State } & \multicolumn{2}{|c|}{ Face to face } & \multicolumn{2}{c|}{ Distance } & \multicolumn{2}{c|}{ State } & \multicolumn{2}{c|}{ Face to face } \\
\cline { 2 - 5 } & Courses & Hours & Courses & Hours & & Courses & Hours \\
\hline Chihuahua & 1 & 10 & 1 & 15 & Colima & 1 & 30 \\
\hline Q. Roo & 1 & 20 & 2 & 89 & Durango & 1 & 14 \\
\hline Sinaloa & 2 & 121 & 5 & 240 & Hidalgo & 10 & 98 \\
\hline Tabasco & 2 & 30 & 2 & 60 & Nayarit & 3 & 24 \\
\hline Tlaxcala & 2 & 18 & 1 & 20 & Tabasco & 1 & 6 \\
\hline & & & & & Yucatán & 4 & 12 \\
\hline Average & $\mathbf{1 . 6}$ & $\mathbf{3 9 . 8}$ & $\mathbf{2 . 2}$ & $\mathbf{8 4 . 8}$ & & $\mathbf{3 . 2}$ & $\mathbf{3 4 . 4}$ \\
\hline
\end{tabular}

Table 3: Hours and training modality by state.

Source: By the authors using information from the CG@

Of the 11 states, 9 were supported by a separate institution in the delivery of their training (Chihuahua, Colima, Durango, Nayarit, Sinaloa, Tlaxcala y Yucatán), while 3 states (Hidalgo, Quintana Roo and Tabasco) used SEP staff exclusively.

GC@ was responsible for reviewing all of the forms in order to give feedback to those responsible in each state. As part of its first review, it informed those states if they did not meet the required criteria so that they could modify their strategies accordingly.

Unsurprisingly, the category of educators that received the most training, both in face-to-face and in distance learning courses, were teachers $(38,941)$, followed by principals. 


\section{Stage 3: Identification of associated costs}

To establish a rubric for the allocation of resources, the GC@ designed a formula that considered: cost per hour for teachers trained on line; cost per hour for teachers trained face-to-face; and, for each state, total cost of face-to-face training. The latter considered the actual cost of face-to-face training in each individual state, taking into account state-based differences. For example, costs were significantly different in Colima, which had fewer teachers and smaller distances to travel for face-to-face training, than Chihuahua, a larger and more spread-out state with more teachers.

For the training, a little more than 1.5 million dollars was allocated in the 13 states that had previously received equipment. The amount distributed was calculated on the basis of the formula just mentioned.

\section{Stage 5: Analysis of the evidence}

The total amount of evidence amounted to some 70,000 files, which the 13 states uploaded to the @prende platform. The state that uploaded the most files was Tlaxcala $(20,766)$, followed by Puebla $(12,569)$ and Sinaloa $(11,476)$. On the flip side, the states that uploaded the least were Zacatecas (377) and Yucatan (188) and Colima (52).

\section{Classification of evidence}

Due to the large amount of information received, the files were classified in three categories: 1 . Training strategies; 2 . Learning; and 3. Class plans ${ }^{5}$

\section{Training strategies}

This category included documents that validated or exemplified the strategy adopted by the state and that provide evidence of the content and the application of the courses given. GC@ received and reviewed 19,034 pieces of evidence (mostly PDF files, images, and spreadsheets) in this category. A subdivision of this classification was made:

- Evidence of training (18,802 evidences) included: convocations, invitations, contracts, receipts, videos and photographs of sessions, attendance list, agendas, work methods, calendars, access codes, reports, testimonies, resources inventories, evaluations, surveys, etc.

- Overviews (2 evidences) included: files displaying content, methods and assessment criteria that were followed in the training of teachers.

The state that provided the most material relating to this category was Tlaxcala $(6,231)$, followed by Durango $(4,028)$ and Puebla $(3,712)$. The least evidence was supplied by Yucatan $(3,712)$, Sonora (184), and Colima (1). Only Hidalgo (222) and Zacatecas (8) chose to conduct surveys.

\section{Learning}

This category consists of documents that relate to the learning process and evidence that demonstrates the activities that the teacher undertook during the training process. The information received consisted of folders by the facilitator or teacher with products, learning sequences, observations, and feedback. Sub-classifications of this category were made of the teacher performance assessments by the facilitators, class observations or reports on the types of products made by the teachers during the course, the types of application used, etc.

\footnotetext{
${ }^{5} \mathrm{~A}$ fourth category was made to account for the files which had problems in terms of being read.
} 
The types of files in this category were mind-maps, presentations, online questionnaires, exercises, essays, etc. In this category, the states that uploaded the most evidence were Sinaloa $(8,789)$, Tlaxcala $(6,086)$, and Puebla $(3,730)$. There were three states that did not upload anything in this category: Chihuahua, Colima, and Nayarit.

\section{Class plans}

Comprising this category were documents with class plans that teachers made as the final product of the training. 19,012 files were registered and classified as didactic sequences, descriptions of activities, projects and tasks to be completed by the students. The states that made the most class plans were Puebla $(4,537)$, Hidalgo $(3,737)$, and Durango $(2,671)$. This category was divided in two:

Didactic sequences: subcategory of documents that include a didactic sequence that indicates the process through which to carry out a project or learning activity. It contained: subject-matter, theme, learning objective, resources to be used, description of activities (start, development, conclusion) and assessment.

- Description of activities: subcategory of documents that include a didactic proposal but do not fulfil the criteria of a didactic sequence and present a summary proposal or description of what was intended for the class.

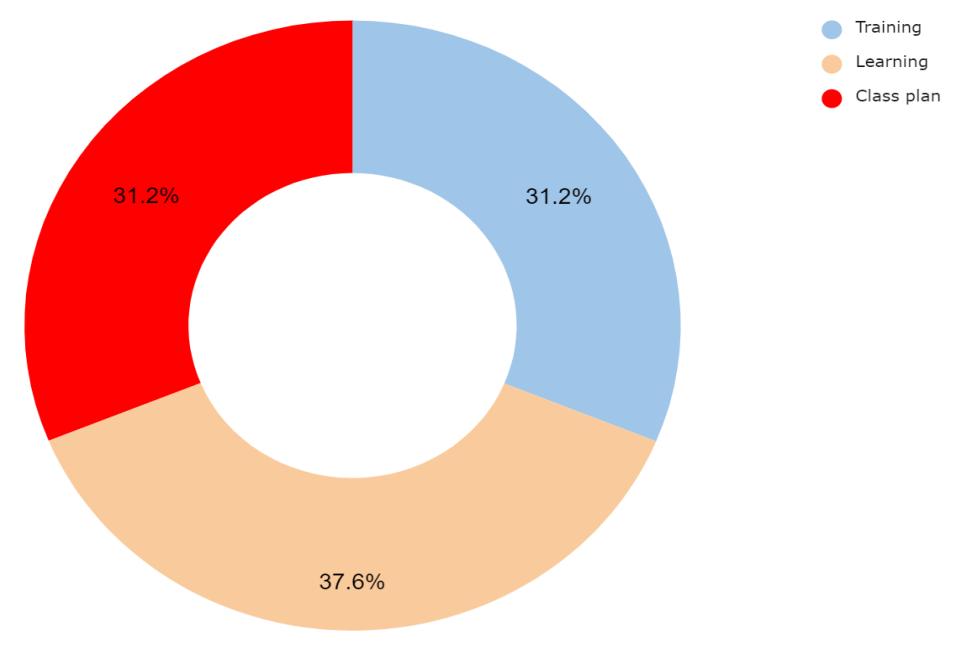

Graph 1: Classification of the evidence.

Source: By the authors using information from the CG@

Due to the excess of information, it was decided to focus solely on analyzing the 19,012 files classified as class plans, ${ }^{6}$ in particular, in the didactic sequences. Some filters were applied to focus the analysis.

\section{First filter}

The following criteria were applied to the didactic sequences:

- Discard any material that did not fulfill the minimum requirements of a sequence (subject, theme, learning objective, resources to be used, description of activities and assessment) even if they were a good idea or project. This was done so that the ones chosen could stand as examples to be replicated in other contexts.

\footnotetext{
${ }^{6}$ The state of Chihuahua presented no evidence or class plan.
} 
- Identify didactic sequences that are very similar to others, in which only the objectives, themes and/or technology to be used change.

- Identify didactic sequences that were either similar or duplicated but with names of different facilitators and teachers.

When applying this filter other criteria were identified that had not been considered initially. Due to their recurrence, they are mentioned here:

- $\quad$ The same plan was presented by multiple teachers. Some plans were the product of group work during teacher training, thus each member of a group of 3 or 4 presented the same plan with a different name (referencing their group).

- The subjects mostly selected were the same (Spanish, history, science, geography and maths). In the plans of one state, only the name of the teacher was changed, along with one or two other minor aspects, and the overall structure and activities were exactly the same as in other plans.

- Some schools presented evidence from other school levels apart from primary (i.e. preschool, secondary school and high-school).

The application of this filter left 3,075 pieces of evidence that fulfilled the minimum requirements to pass to the last assessment for use in identifying the best practices in every state. To be clear, this initial filter removed many evidences. For example, the state of Hidalgo uploaded 3,737 pieces of evidence of which only 349 satisfied the requirements. 500 did not consider any indicator of digital skill; 300 didactic sequences were incomplete; 438 did not use technology and 650 were of similar activities to others.

\begin{tabular}{|l|c|c|c|}
\hline \multicolumn{1}{|c|}{ State } & Class plans & $\begin{array}{c}\text { Fulfilled } \\
\text { requisites } \\
\text { (total) }\end{array}$ & $\begin{array}{c}\text { Fulfilled requisites } \\
\text { (percent) }\end{array}$ \\
\hline Colima & 51 & 46 & $90 \%$ \\
\hline Durango & 2,671 & 336 & $9 \%$ \\
\hline Hidalgo & 3,737 & 349 & $25 \%$ \\
\hline Nayarit & 1,131 & 287 & $18 \%$ \\
\hline Puebla & 4,537 & 355 & $59 \%$ \\
\hline Quintana Roo & 1,785 & 317 & $47 \%$ \\
\hline Sinaloa & 1,247 & 212 & $18 \%$ \\
\hline Sonora & 275 & 161 & $51 \%$ \\
\hline Tabasco & 443 & 206 & $38 \%$ \\
\hline Tlaxcala & 2,127 & 375 & $16 \%$ \\
\hline Yucatán & 379 & 192 & 239 \\
\hline Zacatecas & 629 & 3,075 & \\
\hline Total & 19,012 & & \\
\hline
\end{tabular}

Table 4: Analysis of class plans by state.

Source: General Coordination @prende.mx

During the processing of information various problems were found, including: 
- Low percentage of plans that fulfil the requisites. The number of plans submitted by states varied. The states that handed in the highest number of plans, however, also had the lowest rate of fulfilling the minimum criteria. In total, only $16 \%$ of the plans received fulfilled the requirements of this filter.

- Another aspect, also with $8 \%$, relates to the way teachers worked on and handed in their evidence. The plans that were handed in were the result of training they had received. In some states, the plans were done as a team, yet each member presented the same plan, modifying only the name (they indicated the team they belonged to).

- Another aspect, with between 3 and 6\%, saw evidence presented from different school levels than $5^{\text {th }}$ and $6^{\text {th }}$ grade of primary - i.e. from grades which did not use technology in their plans or have the tablets. We also found plans that could not be replicated as they were only lists of tasks

- Plans with a passive role for students. In the majority of plans, teachers elaborated and introduced the technological product to the group. In such cases, students only reviewed what the teacher did, without playing any part themselves in production. These plans reflected the local pedagogical practice and did not take full advantage of the revolutionary aspects of ICT and digital thinking

- Plans did not include the development of digital skills. Again, some plans allowed students to model a teacher's work by cut-and-paste methods, rather than developing skills to promote the ability of students to investigate, analyze, organize, and produce.

- Technology as extension of textbooks. Some plans did not modify activities and outcomes on the basis of information technology, but rather, just used them to present information from the textbook.

See the following graph:

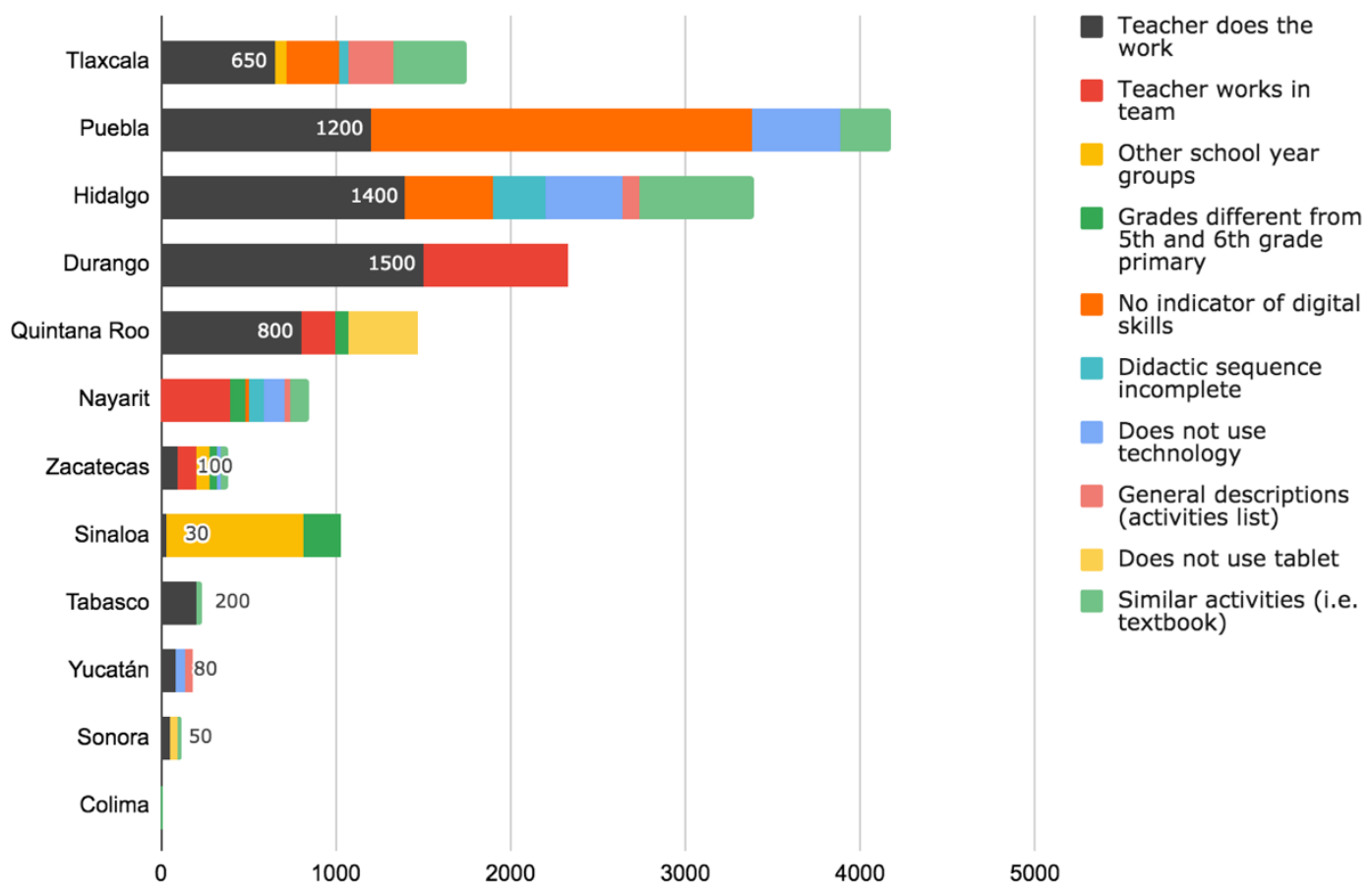

Graph 2: Analysis of class plans by state.

Source: General Coordination @prende.mx 


\section{Second Filter}

GC@ then reviewed the files that passed the first filter, in order to assess the didactic sequences in light of a set of criteria designed by the GC@. 100 possible points were available, taking into account the following considerations:

- General data (5 points): This category includes information that identified the origin of the planning, its location within the curriculum, its learning outcomes or objectives, and the grade of the students who would receive it.

- The minimal amount of evidence would be: (1) Name of teacher (2) Subject (3) Expected learning outcomes (4.) Grade of students (mostly $6^{\text {th }}$ grade primary school children, though some $5^{\text {th }}$ grade).

- Incorporation of the ICT (20 points): This category encompasses the technological resources and applications that the teacher proposed to use in the three stages of a didactic sequence - start, development, and assessment. The plan had to evidence: the use of information technology; the specification of technological resources to be used in the class plan; and that the students would perform at least one activity with the tablet, using one or two technological applications.

- Didactic Strategy (30 points): Two aspects were considered.

- Type of activity proposed by the teacher to incorporate technology into their class plan (10 points)

- Help with technology in the process of teaching and learning (20 points)

GC@ further considered proper pairing of the technological application to the proposed task and objective, the use of information technology by the student to produce (rather than passively consume), and the sequencing of activities to generate a final product.

To pass on to the next stage, the evidence had to show: the completion of activities; indication of the start, development, and conclusion of the plan; and the inclusion of two activities developed by the students themselves - where they do not passively complete activities set by the teacher (for example, where the teacher develops a crossword or a word-search for the students to solve or shows a video).

- Digital Skills (40 points): This category considered whether the following skills were identified and promoted by the tasks and activities proposed by the teacher in their plan: a. Information, b. Communication, c. Digital citizenship, d. Computational thinking.

It was considered that at least one of the four skills should be developed.

- Assessment (5 points): This category took into account the method of assessment to be used by the teacher to grade the students. It also considered how the technological application would be used to automate the results and help in the management of the group. It was considered that, as a minimum, the way of assessing each activity and product would be mentioned.

As can be seen, the average score obtained, based on the assessment of the 3,075 pieces of evidence from the states, was a little lower than 30/100. The highest scores were in the states of Sinaloa, with 43.96 and Colima, with 42.11; while the lowest scores were 12.74 in Yucatan and 15.62 in Sonora.

The scores by criteria were as follows: 


\begin{tabular}{|l|c|c|c|}
\hline \multicolumn{1}{|c|}{ Category } & $\begin{array}{c}\text { Points for } \\
\text { category }\end{array}$ & Average & $\begin{array}{c}\text { Percentage obtained } \\
\text { of the total }\end{array}$ \\
\hline General data & $\mathbf{5}$ & $\mathbf{4 . 4 9}$ & $\mathbf{9 0 \%}$ \\
\hline Incorporation of ICT & $\mathbf{2 0}$ & $\mathbf{1 3}$ & $\mathbf{6 5 \%}$ \\
\hline Didactic strategy & $\mathbf{3 0}$ & $\mathbf{9 . 9 1}$ & $\mathbf{3 3 \%}$ \\
\hline Type of activity & 10 & 1.58 & $16 \%$ \\
\hline $\begin{array}{l}\text { Help of technology teaching and } \\
\text { learning }\end{array}$ & 20 & 8.33 & $42 \%$ \\
\hline Digital Skills & $\mathbf{4 0}$ & $\mathbf{2 . 0 7}$ & $\mathbf{5 \%}$ \\
\hline Information & 10 & 0.71 & $7 \%$ \\
\hline Communication & 10 & 1.02 & $3 \%$ \\
\hline Digital citizenship & 10 & 0.26 & $1 \%$ \\
\hline Computational thinking & 10 & 0.13 & $\mathbf{9 \%}$ \\
\hline Assessment & $\mathbf{5}$ & $\mathbf{0 . 4 4}$ & $\mathbf{3 0 \%}$ \\
\hline Total & $\mathbf{1 0 0}$ & $\mathbf{2 9 . 9}$ & \\
\hline
\end{tabular}

Table 5: Results based on the assessment criteria, by state.

Source: General Coordination @prende.mx

Note: the state of Chihuahua was removed as it did not hand in any plans.

The table above shows that the class plans were limited in quality. This was highlighted by the low scores obtained for the inclusion of activities which promote digital development skills as well low scores for the inclusion of ways to assess those skills.

In relation to the incorporation of ICT in the teaching process, the score was $65 \%$ of the possible total. This meant that more than half of the lesson plans did incorporate technological elements in their didactic sequences. However, regarding all of the other criteria, the scores were less than $50 \%$. Regarding this, the GC@ found that there was a significant relationship between tools that were presented to the teachers in their training courses, and what those same teachers used in their class plans. This suggests that teachers do not, generally, have their own views about tools and are more likely to use those proposed by trainers.

The score for the criterion of didactic strategies is striking, given that it is around half that of the score for the criterion of incorporation of ICT in lessons plans. This suggests that the training was not sufficient for the teacher to adequately include the practical use of information technology in the teaching-learning process - a situation that was also observed in relation to other criteria.

Regarding digital skills, the results show a lack of knowledge on the subject. This could be due as much to conceptual aspect as to the implementation of the class plan. The data show that a true understanding of incorporating technology into the classrooms had not been conveyed to teachers.

The low standard of the class plans is also seen in relation to assessment. In light of this, it is considered important to find ways to help the teacher become more aware of the significance and benefits of incorporating technology within the classroom, by highlighting its pedagogical aspects in the creation of teaching strategies using technology.

The work carried out by the GC@ serves as the point of departure for the training of teachers in Mexico. The degree of freedom given to states for the design of their strategies allowed for the observation of the differences that exist between various regions. However, a methodology capable of generating more homogenous results could be useful for future analysis. 


\section{Results by state}

The results obtained by the GC@ show significant variance between the 13 states that uploaded evidence to the platform. The following graph shows that the states of Colima, Durango, Hidalgo, Puebla, Sinaloa, Tabasco and Zacatecas scored above the average, while Nayarit, Quintana Roo, Sonora and Yucatan scored lower. ${ }^{7}$

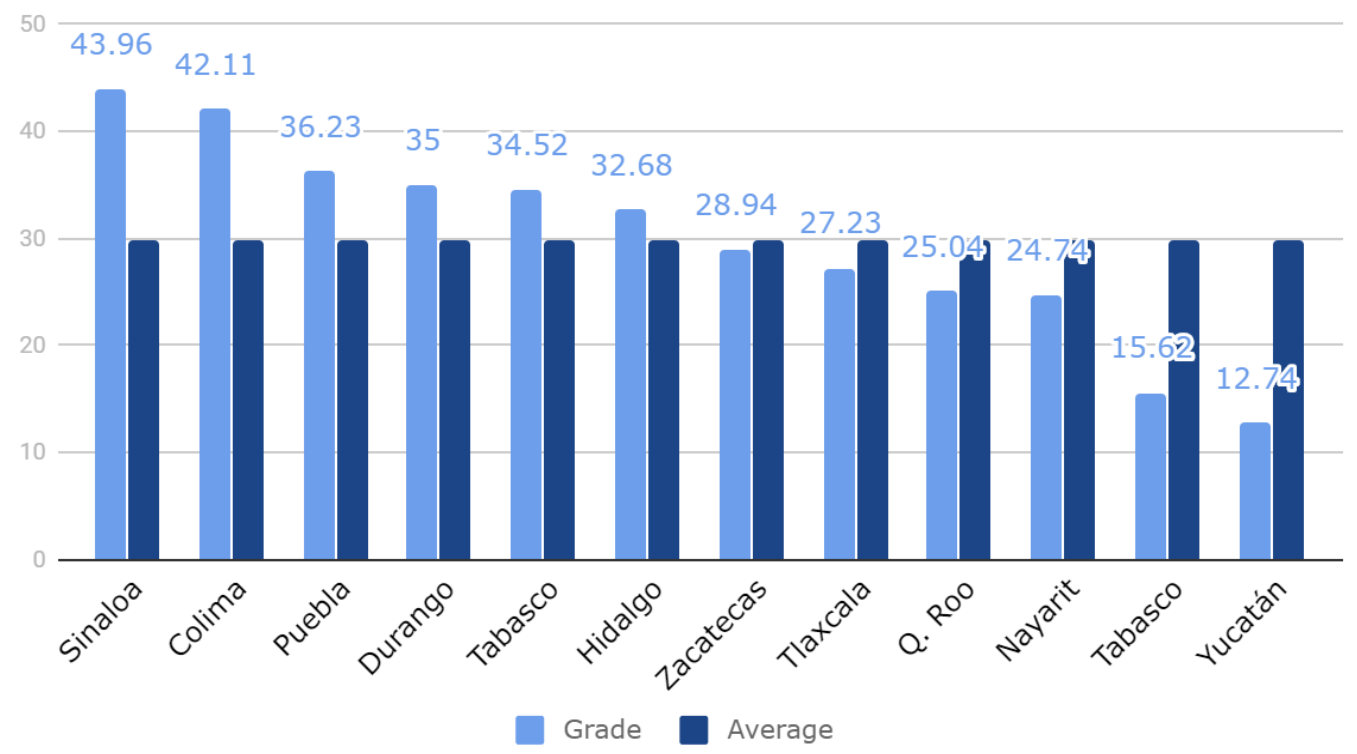

Graph 3: Results based on assessment criteria, by state.

Source: General Coordination @prende.mx

Note: the state of Chihuahua was removed as it did not hand in any plans.

In the next graph, it can be observed that there is no direct relationship between the number of hours dedicated to training and the score obtained by the state. While Sinaloa, the state which obtained the highest score, dedicated the most hours to training; Quintana Roo, which dedicated the second most amount of time to training, was below average.

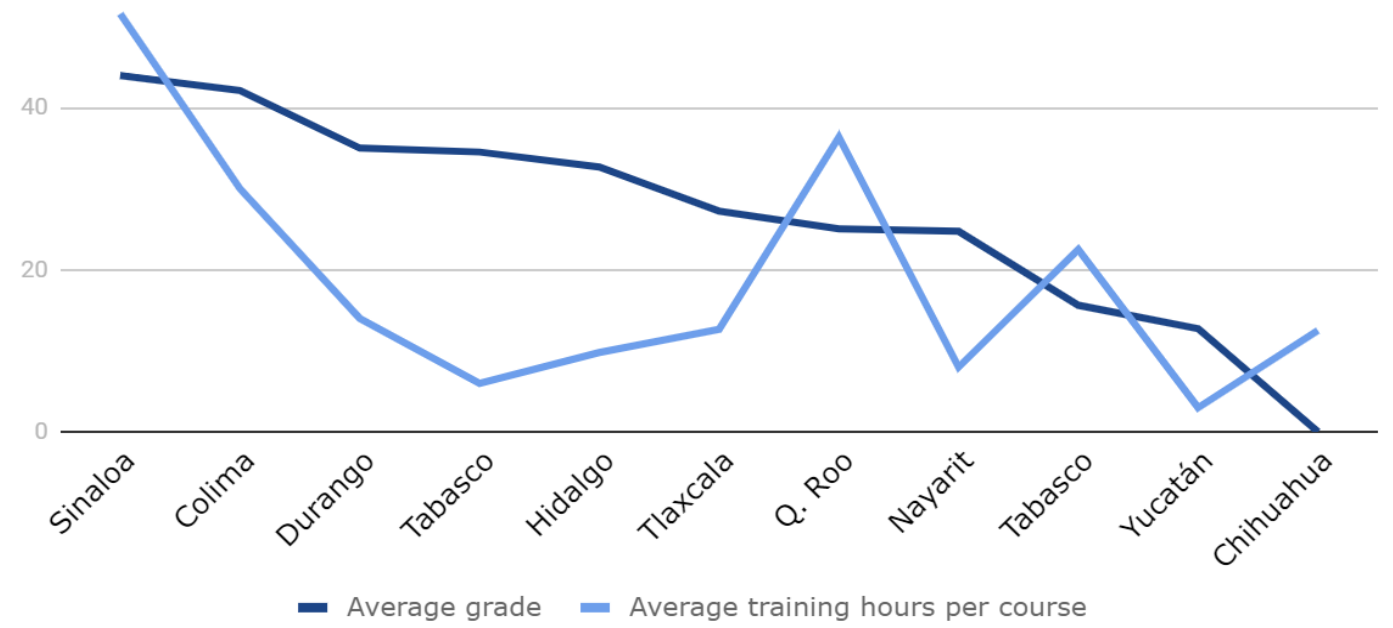

Graph 4: Relation between score and hours of training, based on assessment criteria by state.

\footnotetext{
${ }^{7}$ The state of Chihuahua did not upload any plans to the platform.
} 
Source: General Coordination @prende.mx

Note: the state of Chihuahua was removed as it did not hand in any plans.

In a similar way, no direct relationship was found between the score and the modality of the training - i.e. whether it was face-to-face or distance learning. The above suggests that the score depended largely on the prior knowledge of the teacher. This means that it is necessary to reevaluate the contents and format of the training given.

\begin{tabular}{|l|c|c|c|c|c|c|}
\hline & \multicolumn{5}{|c|}{ Score by Category } \\
\hline State & $\begin{array}{c}\text { General } \\
\text { Data }\end{array}$ & $\begin{array}{c}\text { Incorporati } \\
\text { on of ICT }\end{array}$ & $\begin{array}{c}\text { Didactic } \\
\text { Strategy }\end{array}$ & $\begin{array}{c}\text { Digital } \\
\text { Skills }\end{array}$ & $\begin{array}{c}\text { Assessmen } \\
\text { t }\end{array}$ & Average \\
\hline Sinaloa & 3.98 & 18.42 & 2.58 & 6.59 & 0.50 & 43.96 \\
\hline Colima & 4.98 & 17.76 & 3.80 & 3.76 & 0.39 & 42.11 \\
\hline Puebla & 5.00 & 17.56 & 1.54 & 1.02 & 0.55 & 36.23 \\
\hline Durango & 5.00 & 15.92 & 1.58 & 0.46 & 1.17 & 35.00 \\
\hline Tabasco & 4.89 & 11.64 & 1.39 & 4.57 & 1.18 & 34.52 \\
\hline Hidalgo & 4.51 & 15.45 & 1.48 & 2.69 & 0.14 & 32.68 \\
\hline Zacatecas & 4.62 & 11.57 & 2.40 & 2.85 & 0.47 & 28.94 \\
\hline Tlaxcala & 4.45 & 13.61 & 0.76 & 0.94 & 0.23 & 27.23 \\
\hline Q. Roo & 4.58 & 10.49 & 1.44 & 0.95 & 0.08 & 25.04 \\
\hline Nayarit & 3.93 & 11.71 & 1.17 & 0.79 & 0.49 & 24.74 \\
\hline Tabasco & 4.55 & 6.98 & 0.43 & 0.16 & 0.09 & 15.62 \\
\hline Yucatán & 3.35 & 4.84 & 0.42 & 0.02 & 0.01 & 12.74 \\
\hline Average & $\mathbf{4 . 4 9}$ & $\mathbf{1 3 . 0 0}$ & $\mathbf{1 . 5 8}$ & $\mathbf{2 . 0 7}$ & $\mathbf{0 . 4 4}$ & $\mathbf{2 9 . 9 0}$ \\
\hline
\end{tabular}

Table 6. Score by category, results based on the assessment criteria, by state.

Source: General Coordination @prende.mx

Note: the state of Chihuahua was removed as it did not hand in any plans.

Viewing the scores broken down by state and by criteria, we can observe the following:

- The states with the best average ratings (Sinaloa, Colima, and Puebla) also stand out in the criterion of ICT incorporation. This is unsurprising as this criterion best explains results of the incorporation of technology in the classroom.

- The state with the highest score based on the assessment criteria was Sinaloa. Nevertheless, the total of the score of that state was only 43.96 - it gained less than half the possible points. This illustrates that, despite the fact that the didactic sequences of the state considered the incorporation of ICT, they failed to fully understand and utilize ICT in their plans.

- The category of digital skills was one of the lowest scores. This shows that different mechanisms to achieve more effective training are required.

- Generally, across the rest of the subjects - apart from general data - the scores were low.

- $\quad$ The scores obtained were below those expected given the scale applied. 


\section{Conclusions, Lessons and Recommendations}

\section{a. Conclusions}

- The results suggest that it is necessary to carry out more work with the teachers prior to training so that they are better equipped to align themselves with the objectives of the training.

- For primary school teachers to incorporate ICT into the curriculum, it is not enough for them to master their subject; teachers must also understand the pedagogical-didactic foundation of the teaching-learning process, as well as the potential of technology (the internet and its tools).

- $\quad$ Although the aim should not be for teachers to achieve mastery of information technology, it is necessary that they learn about these tools and about their didactic potential. Otherwise they will not see the benefits of their implementation in the teaching - learning process. Teacher training must direct its attention to the necessity of learning to use technology. It must be motivated and start from the contradiction between the real possibilities available and the aspirations of its employment for the optimal performance of the professional work.

- The training results show that training cannot be generalized; training tailored to each state reflects an improvement in the incorporation of ICT as tools for learning support. The teachers that went from level 1 to level 3 created their own material and learning sequences.

- The states that followed the guidance of the criteria to achieve level 1 of the UNESCO framework were the ones that presented the most evidence of developing skills in creating projects, creating solutions to specific problems, searching for and critically analyzing information, self-assessing work, working collaboratively, and overall, being producers rather than consumers - of information technology.

- The use of ICT in the teaching-learning process does not just depend on teacher training. As Trucco and Espejo (2013) affirm, other factors include: contextual factors; ${ }^{8}$ factors personal to the teacher; ${ }^{9}$ programmatic factors, ${ }^{10}$ as well as school factors. ${ }^{11}$

\section{b. Lessons}

- States are willing to participate in a well-funded teacher training effort. The implementation of the process requires more intensive work in following up with the states to make sure that the training has taken hold, that information from the states is being provided, and that questions from the teachers are being addressed.

- States often have problems providing documentation required for federal support. The states that did not participate were those that could not deliver the required documentation.

- In the area of pedagogy and didactics, teachers were unwilling or unable to leverage the potential of ICT use in the effective design of didactic units in teaching areas. The assessment indicators have not been modified.

\footnotetext{
${ }^{8}$ For example, geographical - e.g. rural or urban, capital or provincial; the grade taught as well as the sociocultural make up of the school.

9 For example; length of time as a teacher; ICT access at home (PC, laptop, internet); the subjective assessment by teachers of the changes of the program - whether or not they consider it to be optimal use of teaching time, an improvement of learning quality, something which motivates students.

${ }^{10}$ For example; training courses /the availability of dynamic support staff.

${ }^{11}$ For example; Use of device; high motivation of the principal; age of the principal and presence of ICT resources in school planning.
} 
- Sufficient evidence reflects that didactice sequences involving ICT motivate students, and thus should increase teacher motivation for the use of ICT.

- For all its potential, ICT by itself cannot transform existing pedagogical practice without teacher buy-in.

\section{c. Recommendations}

- Although the class plans contained the required information for the identification and setting of objectives, future programs should consider guidelines that, without limiting creativity, push quality beyond a minimal level.

- Future programs should provide the means to guarantee that the proposals of the states satisfy the desired criteria. If technology could be used to avoid the uploading of proposals that do not meet the minimum required, it would focus efforts of the teachers, reinforce the core principles of the training, and save administrative costs.

- Future programs should develop a better filter for uploading evidence for each state, in light of the experiences described above. Specifically, the absence of a classification by type of evidence complicated the analysis.

- Future training should focus on using ICT to achieve contextually specified goals, with an eye firmly on developing digital skills. Rather than lesson plans drawn from textbooks and supplemented by ICT, or lessons describing the use of a particular type of ICT to solve a problem, students should be guided on using ICT to produce solutions. For example, in the case of digital citizenship, rather than learning to block sites, students should learn to use ICT to contrast various sources of information and determine if information was true or not; or how to manage their social networks; or what to do in cases of cyber-bullying, etc.

- Teachers should be presented with practical examples of the development of digital skills. These must clearly specify which digital skills are going to be developed, justifying the technology and applications to be used, ensuring that technology will be used by students and not just by teachers, including assessment criteria, and uploading evidence of student achievement so that they can be compared to teachers, etc.

In short, teacher training is an essential element of the integration of ICT in the teaching-learning process. While critical, such training is extremely complicated as the case study shows, and must be designed to give both direction and room for flexibility to be effective.

\section{References}

Cardelli, J. J., \& Duhalde, M. A. (2001). Formación docente en América Latina. Una perspectiva Política - Pedagógica. Artículo publicado en Cuadernos de Pedagogía N³08, Dic. 2001, Barcelona. Francesc, P. (2015). Tecnología para la mejora de la Educación: Experiencias de éxito y expectativas del futuro. Documento Básico. Fundación Santillana. Disponible en: http://www.fundacionsantillana.com/semana-delaeducacion/documentos/DOC_BASICO_2015-INTERIORES.pdf

Franzoni, A.L., Cardenas, C., \& Almazan, (2019). Using Blockchain to store teacher's certification in basic education in Mexico. IEEE 19th International Conference on Advanced Learning Technologies (ICALT).

Murillo, F. J. (2005). Estudios sobre Eficacia Escolar en Iberoamérica. Convenio Andrés Bello. Bogotá. 
Trucco, D. y Espejo, A. (2013). Principales determinantes de la integración de las TIC en el uso educativo: el caso del Plan Ceibal del Uruguay. Políticas sociales. 177. Recuperado de http://repositorio.cepal.org/handle/11362/6191

UNESCO, 2016. Marco de competencias para los docentes en materia de TIC de la UNESCO. Disponible en: http://unesdoc.unesco.org images/0021/002134/213475e.pdf, fecha de consulta: 17 de agosto de 2016. 